\title{
COMMUNICATIVE ILLOCUTIONARY ACT ON STUDENTS' CONVERSATION VIDEO IN ONE OF THE ENGLISH COURSES IN BANDUNG
}

\author{
Mu'man' \\ ${ }^{1}$ IKIP Siliwangi \\ ${ }^{1}$ mumanresearch@gmail.com
}

\begin{abstract}
Speech acts are divided into three categories - locutionary, illocutionary, and perlocutionary. Each speech act can be investigated based on the researcher's need what it is done in this research purpose of this study aiming to find out the context meaning of communicative illocutionary act categories on students' conversation video. The spirit of the speech act can be called as illocutionary which becomes a central concept. Regarding to the definition of speech acts, several numerous options related to illocutionary have some kinds of acts such as promising, ordering, and bequeathing. This research uses Austin's book as a grant theory strengthened by Yule. This research result is the researcher has found communicative illocutionary acts on students' conversation video including constatives, directives, commissives, and acknowledgments.
\end{abstract}

Keywords: Illocutionary, Constative, Directives, Commissives

\section{INTRODUCTION}

As we know that language develops rapidly. It seems from every human speech that sometimes people cannot understand the conversation each other or needs the deepest understanding of the meaning context. It is because language cannot be apart from pragmatics. A conversation can be understood if both speakers and listeners can understand the context. Then, it is impossible that a conversation happens if either speaker or hearer cannot understand the context.

Because the main role of a conversation is to deliver pragmatic's understanding either speakers or hearers, it appears that pragmatics has an important aspect in language context. It is actually also said that pragmatics how language can be understood through the context and ways people produce and give an understanding through language's meaning - spoken, written, or signed. On the order hand, pragmatics give an explanation about people intending language meaning, assumption, purpose, or goal, so that it may affect an act for the hearers.

In language science as a brand of linguistics, pragmatics studies about how language context contributes the meaning. Then, it consists of speech act, conversational implicature, deixis, cooperative principles, and politeness principles. It has been formulated that pragmatics has a broad concept in linguistics and it also has an important role in giving the meaning context in every language. In line with this, Yule (1996) stated pragmatics concerns to the study of meanings. It is communicated by a speaker or writer and interpreted by a listener or reader. On the other hand, pragmatics is a linguistic knowledge which discusses or interprets the speakers' or writers' purposes. The key of understanding the utterances and writings is how people understand pragmatics as a knowledge in interpreting the meaning. 
As what has been explained above, there are five concepts of pragmatics - speech act, deixis, conversational implicature, cooperative principles, and politeness principles. In this research, this will be focused on speech acts as the limitation of study. Yule stated (1996) that the intention of speech acts concerns with the speakers' communication, so that it will produce the utterances which have a purpose to request, apologize, and report delivered by the speakers.

A speech act in linguistics and the philosophy, language can also be mentioned as an utterance which has a performative function. In addition, it is not only in written text and spoken context but in the world communication mass media cannot be apart from language to transmit and produce messages for the large publics which could bring any different comprehension and the audiences will seek, use, and understand its messages (Littlejohn, 2010).

The performance of speech acts is always performed at once even it is presented by several acts. This distinguished some different aspects of speakers' intention. For instance, how someone says something and she or he spits it out. The words could be a request or promise. The role of those utterances is trying to give the effects to the audiences (Bach, 1979). Another statement comes from John R. Searle (1985), the meaning of speech acts regularly gets in touch with similar things as the acts of illocutionary.

The theory of speech acts is to make people understand meaning context and to dig it from discourse's surface which can establish the utterance's function (Cook, 1992). In line with this, there are three levels which have to give more attention;

1. The utterance's performance called as locutionary act acquires either ostensible or actual meaning which comprise rhetic, phatic, and phonetic acts. This will correspond to meaningful utterances covered by the aspects of verbal, syntactic, and semantic.

2. The pragmatic of utterances called as illocutionary act. It intends a valid or verbal significance action especially in social context.

3. The actual effect presented by perlocutionary is not intended to persuade, scare, convince, inspire, or enlighten in order that someone can do and realize something.

From those three levels above, the researcher focuses on illocutionary act as the spirit of the speech act.

The illocutionary type is very interesting because it always has a performative utterance's performance (Auatin, 1962). In example, the sentence of (I nominate Mike to become a president) and (the judges punish you imprisonment for ten years), or (I swear I will pay her back). Those sentences' example refers to performatives therefore they show the action and describe the installation, punishment, and appointment. And, they are shown explicitly. Then, speech acts might be classified into four types - assertion, promise, request, and apologizing. Those were broken down by illocutionary.

Besides, Bach (1979) mentioned that the illocutionary act can perform the speaker deliver the meaning or message to listeners in order to understand trough mutual contextual beliefs (MCB). This distinguishes the attitude's speaker's type when they are expressing something. It corresponds to such kind of certain attitude to form or shape the listeners behaviour so that they will have correlative attitudes as the goals of perlocutionary. Four major categories of illocutionary acts, which may be called as;

a. Constatives: affirming, announcing, answering, attributing, claiming, concurring, confirming, classifying, conjecturing, alleging, denying, disagreeing, disclosing, disputing, identifying, informing, insisting, predicting, ranking, reporting, stating, stipulating 
b. Directives: advising, admonishing, begging, dismissing, asking, excusing, forbidding, instructing, ordering, permitting, requesting, requiring, suggesting, urging, warning

c. Commissives: agreeing, betting, guaranteeing, inviting, offering, promising, swearing, volunteering

d. Acknowledgments: apologizing, condoling, congratulating, greeting, thanking, accepting (acknowledging an acknowledgment)

In line with this research, Anderson (2018) stated that the same major categories of speech acts - assertives, directives, commissives, expressives, and declarations. Related to this research, several researchers have conducted using speech act as a theory. Yet the researcher takes two previous studies which are related to this main topic of this research. First, it was taken from Sahar Farouq Altikriti written in 2011 from Dept. of English Language, the University of Al Isra, Amman, and, Jordan. It analysed speech acts in short stories. They identified or pinpointed what is a context is difficult. The result it short stories were used fluctuatively either type or quantity which mean this fluctuates theme or writer to another.

Second was analyzed from Samuel's paper written in 2013 from English Department Studies and Akungba-Akoko. Nigeria. The title of the research was about explaining the analysis of speech acts in speech's contest between Chief Obafemi Awolowo and Chief M.K.O. Abiola. This study investigated language communication role and intentions' interpretation about political speech on discourse with specific goals. The result found there are five categories of speech acts identified - assertive acts, expressive acts, commissive acts, directive acts, and declarative acts.

Based on the researches above analyzed using speech act theory, the researcher will focus on investigating the kinds of communicative illocutionary acts on students speaking conversations video under the title "Communicative Illocutionary Act on Students' Conversation Video in One of The English Courses in Bandung”.

\section{METHOD}

This research uses content analysis which the sources of the data were taken from the students' conversation video between two people (speaker and hearer). This research naturally analyzed the kinds of illocutionary acts based Yule's theory (1996) with content analysis as its method. Content analysis is one of the research techniques used to constitute valid conclusions from texts or other meaningful materials to the context used (Krippendorf, 2018). It is said that content analysis can be used to conduct the research which is related to the text and the result which can be taken and concluded to the desired context by the researchers.

In line with this, content analysis is defined as a procedure for the categorization of verbal or behavioral data for purposes of classification, summarization, and tabulation (Hancock, 2002, p.21). This means content analysis is used to categorize the data either verbal or behavioral. Then, it has a purpose that the data taken from the object can be classified, summarized or tabulated as the real data.

\section{RESULTS AND DISCUSSION}

\section{Results}

From the data taken on students' English conversation video, the researcher found the words which are included into constatives, directives, commissives, and acknowledgments. 
Constatives, - Concurring and informing, from the data analysis, the researcher found the students' words categorizing into concurring and informing.

a. Concurring

The data are;

Data 1 : I will take care.

Data 2 : Ok you can count on me.

It can be seen from the sentences above that the speaker showed the concurring to take care something and he/she can be counted on.

b. Informing

The data are;

Data 3 : I'm in Borma. What's up?

Data 4: Ok, I'm going to the college. Please keep the water. Please I am filling the bucket.

Data 5 : I'm not take a bath. (I am not taking a bath).

Data 6 : Sorry I forget. I have a picket, so I forgot.

Data 7 : Before I go

From the sentences above, we can see that whether first speaker and second speaker inform each other about their activities in the present. It shows that the information is so important to make the hearer understand what we are doing, have done, and did. With this information, either first speaker or second speaker will not misunderstand for what they deliver the meaning purposes.

Directives, from the data analysis, the researcher found the students' words categorizing into admonishing, asking, and requesting.

\section{c. Admonishing}

The data is;

Data 8 : Next time you don't be like that again you must be responsible.

Admonishing is to make the people not to do the same thing. It can be seen in the sentence above that the speaker admonishes the hearer not to do the bed thing again because the speaker thinks that the hearer will be responsible about keeping the water in his room. The fact, the hearer is not responsible and let the water be overflowing from the bucket.

\section{d. Asking}

The data are;

Data 9 : Where are you Fadli?

Data 10 : I'm in Borma. What's up?

Data 11 : Oh, you forget? (Do you forget?)

Data 12 : When eat? (When have you eaten?)

Data 13 : What eat? (What have you eaten?) Use rice? (Have you eaten rice?)

Asking is to know about the information of thing or person. In this case, the speaker gives the information. From the questions above, there is a question needed the answer yes/no and there is a question needed the information answer. Information question seems like needing more specific answer, but yes/no question seems like needing a simple answer.

\section{e. Requesting}

The data are;

Data 14 : ok, I'm going to the college. Please keep the water. Please I am filling the bucket.

Data 15 : Let's eat. I will treat you.

It can be seen from the sentences above that the speaker asks to do something. Keep the water means that the hearer must keep the water in other not to be overflowing and let's eat means that the speaker asks the hearer to have eating together. These all can be called as a request. 
Commissives, from the data analysis, the researcher found the students' words categorized into agreeing and promising.

\section{f. Agreeing}

The data is;

Data 16 : Let's see. Come on!

The data analysis above sees that the speaker agrees with the hearer to do something. He also asks his friend together to see what happens in the other place.

g. Promising

The data are;

Data 17 : I will take care.

Data 18 : Yes maybe next time I will responsibility. (I will be responsible)

It can be seen from the sentences above that the speaker promises to do what his friend has asked to him. He promises that he will be responsible about the request and he will take care of it.

Acknowledgments, from the data analysis, the researcher found the students' words categorizing into apologizing and thanking.

h. Apologizing

The data is;

Data 19 : Sorry I forget. I have a picket, so I forgot

Apologizing is the sign of regretting doing the careless thing. From the sentence above, it can be seen that the speaker apologizes to his friend because he forgot to do something that he had promised to do it for his friend. He speaks the word 'sorry' because he regrets himself for what he has done.

i. $\quad$ Thanking

The data are;

Data 20 : Ok Thanks

Data 22 : I must say thanks.

It can be seen from the sentence above that the speaker says thanks. It shows that he gives respect each other. Even the bed thing happens to them, but they still can get along.

\section{Discussion}

From the data taken on students' English conversation video, the researcher found the words which are included into constatives, directives, commissives, and acknowledgments. Constatives, - Concurring and informing, from the data analysis, the researcher found the students' words categorizing into concurring and informing.

\section{CONCLUSION}

Based on finding and discussion, communicative illocutionary act was addressed on the students' English conversation video. It has been proved that the researcher found 21 data which were divided into constatives, directives, commissives, and acknowledgements. In the form constatives, the researcher found seven data. Two data belongs to concurring and the others are related to informing.

It has been found eight data related to directives. One data refers to admonishing, five data refer to asking, and the others refer to requesting. There are three data related to commissives. One is for agreeing and two other data are for promising. The data found in acknowledgements have 
the number of commissives -3 data. One data is related to apologizing and two other data are related to thinking. From the result of this research, it can be seen that the data related to directives dominates four other kinds of communicative illocutionary act - constatives, commissive, and acknowledgements. It is seen that eight of twenty-one data which have been analyzed are related to directives. Meanwhile, thirteen data refer to the others.

\section{ACKNOWLEDGMENTS}

Thank to my family who have given me support both morally and materially, so that I can complete and publish my article

\section{REFERENCES}

Anderson, J. (2018). Applying Speech Act Theory To Regional Integration. Discussion Papers. Austin, J. L. (1962). How To Do Things With Words. London: Clarendon Press.

Bach, K., \& Harnish, R. M. (1979). Linguistic Communication And Speech Acts.

Cook, V. J. (1992). Evidence For Multicompetence. Language Learning, 42(4), 557-591.

Hancock, B. (2002). Research And Development In Primary Health Care: An Introduction To Qualitative Research.

Krippendorff, K. (2018). Content Analysis: An Introduction To Its Methodology. Sage Publications.

Littlejohn, S. W., \& Foss, K. A. (2010). Theories Of Human Communication. Waveland Press.

Searle, J. R. (1985). Expression And Meaning: Studies In The Theory Of Speech Acts. Cambridge University Press.

Yule, G. (1996). Pragmatics: Oxford University Press. 